\title{
Practices required by practicing teachers of Agricultural Education in soil pH management for effective teaching of students in junior secondary schools in North-Central Nigeria
}

\author{
V. C. Asogwa ${ }^{1 *}$ and M. N. Omeje ${ }^{2}$ \\ ${ }^{1}$ Department of Agricultural/Home Economics Education, Michael Opkara University of Agriculture, Umudike, Abia State, \\ Nigeria. \\ ${ }^{2}$ Department of Agricultural Education, University of Nigeria, Nsukka, Enugu State, Nigeria. \\ *Corresponding author. Email: asovinchidi@yahoo.com \\ Copyright @ 2017 Asogwa and Omeje. This article remains permanently open access under the terms of the Creative Commons Attribution License \\ 4.0, which permits unrestricted use, distribution, and reproduction in any medium, provided the original work is properly cited. \\ Received 22nd June, 2017; Accepted 5th July, 2017

\begin{abstract}
This study focussed on practices required by practicing teachers of agricultural education for effective teaching of soil pH management to students in junior secondary schools in North-Central Nigeria. Three objectives were developed to guide the study and questionnaire survey research design was used. The study was carried out in NorthCentral Nigeria. The population of the study was Fifty-five (55). Soil pH Practices Questionnaire (SPPQ) was used for data collection. The SPPQ was face validated by Three (3) experts. Cronbach Alpha coefficient of 0.89 was obtained as the internal consistency of the SPPQ items. The data collected was analysed using mean and t-test statistics. It was found, among others, that the practicing teachers of agricultural education from Colleges of Education required Twelve (12) practices in determination of soil $\mathrm{pH}$. Recommendation was that lecturers of Agricultural Education in Colleges of Education should utilize the identified practices in soil pH to train students in Colleges of Education.
\end{abstract}

Key words: Agricultural education, liming, practices, practicing teachers, soil $\mathrm{pH}$, teaching practice.

\section{INTRODUCTION}

The need to impart knowledge and skills in agriculture to the younger generation emerged when the demand of agricultural produce by the consumers became greater than the supply by the farmers in the market in Nigeria. This condition forced the government to introduce agricultural education into the education system in Nigeria. Williams (1991) stated that Agricultural education encompasses the study of applied sciences (Biology, Chemistry, Physics), and business management principles in agriculture. One of the major purposes of agricultural education is to apply the knowledge and skills learned in several different disciplines to agricultural education. Martin (1991) expressed that agricultural education focuses on the needs of individuals and groups and in developing individually satisfying and socially responsible knowledge, skills, and o ccupational values.
Osborne et al. (2008) defined Agricultural Education as the teaching of agriculture, natural resources and land management through hands on experience and guidance to prepare students for entry level jobs and to further education to prepare them for advanced agricultural jobs. The authors emphasized that Agricultural education is taught to students at the elementary level, middle school level, secondary education, post-secondary education and higher levels education such as Colleges and Universities.

A College of Education, according to National Policy on Education (2004) is a tertiary institution that prepares individuals as teachers within a-three year duration for teaching agriculture subject in primary and junior seconddary schools. In Colleges of Education, the objectives of agricultural education programme as contained in the 
Minimum Standard prepared by the National Commission for Colleges of Education (2009) are to:

1. prepare graduates with the right attitude to, and knowledge/professional competence in vocational agriculture;

2. produce teachers who will be capable of motivating students to acquire interest in and aptitude for agriculture;

3. develop in the student-teachers the appropriate communicative skills for effective transmission of agricultural information and skills to the students in the context of their environment;

4. equip the student-teachers with adequate knowledge and ability to establish and manage a model school farm effectively and

5. provide a sound background to enhance further academic and professional progression of the student-teachers.

The above objectives are achieved with the help of lecturers of agricultural education who prepare students in both pedagogical and technical areas of agriculture for effective teaching in nursery, primary and junior secondary schools. During this period of teacher's preparation, the students are at certain stage of their programme, sent to schools such as junior secondary schools to engage in teaching practice to enable them acquire on the job knowledge, skills and attitude that will make them fit into the profession on graduation.

Teaching practice is therefore an important component of agricultural education programme. Salawu and Adeoye (2002) described teaching practice as a practical teaching activity by which the student-teachers are given opportunity in actual school situations to demonstrate and improve training in pedagogical skill over a period of time. Menter (1989) perceived teaching practice as 'the crux of the students' preparation for the teaching profession' since it provides for the 'real interface' between studenthood and membership of the profession. Ngidi and Sibaya (2003) emphasize that teaching practice grants student teachers experience in the actual teaching and learning environment. During teaching practice, the student teachers otherwise known as practicing teachers are given the opportunity to try the art of teaching before actually getting into the real world of the teaching profession (Kasanda, 1995).

In the statement of Farlex (2009), a practicing teacher is a college student who is teaching under the supervision of a certified teacher in order to qualify for a degree in education. In this study, practicing teachers are students of agricultural education from Colleges of Education who are in junior secondary schools to demonstrate their competence in agriculture and improve on their training in technical and pedagogical skills over a period of time. One of the aspects of agricultural curriculum in junior secondary schools in which the practicing teachers are expected to teach students and improve upon includes soil $\mathrm{pH}$.

Soil $\mathrm{pH}$ is one of the chemical properties of soil. It is measured on a scale of 1 to 14 , with 7 as the neutral mark. According to Brady and Weil (2010), soil pH is a measure of the acidity or alkalinity in the soil. The range of $\mathrm{pH}$ scale for most soils is from 4 to 10 . The $\mathrm{pH}$ scale is logarithmic, meaning that a change in one numerical $\mathrm{pH}$ unit equals a 10 -fold change in acidity or alkalinity. For example, a soil with a pH of 8 is ten times more alkaline than a soil with a pH of 7 . Das (2012) asserted that soil $\mathrm{pH}$ is a measure of the hydrogen ion $\left(\mathrm{H}^{+}\right)$activity in the soil solution and it is expressed in $\mathrm{g}$ ion $1^{-1} \mathrm{or} \mathrm{ML}^{-1}$. Soil $\mathrm{pH}$ rises or falls depending on the impact of a range of factors, including farming practices. Gliessman (1998) observed that the importance of soil $\mathrm{pH}$ includes that it affects the availability of essential plant nutrients and the microbial activities of living organisms. Yost and Uchida (2000) stated that a soil is said to be acidic if the numerical pH unit is less than 7 and alkaline when it is greater than 7. The authors emphasized that if a soil pH falls below or rises above certain optimum levels for biological and chemical activities, the soil will become much less productive. For example, common crops like alfalfa, corn and small grains are well adapted to soil $\mathrm{pH}$ ranging from 5.7 to 8.1 . Beyond this range, increasing incidences of nutrient deficiency and growth reduction may occur. This might be why Gale et al. (2001) advised that the $\mathrm{pH}$ status of a garden soil should always be ascertained and managed to reduce or increase it depending on the $\mathrm{pH}$ requirement of the crop that is to be grown on it.

Management, in this study, is the act of handling and keeping control of soil $\mathrm{pH}$ to obtain maximum crop yields from the soil. It entails all the treatment given to the soil to maintain, increase or reduce soil $\mathrm{pH}$ depending on the crop requirement. Anderson et al. (2013) remarked that the first step in soil $\mathrm{pH}$ management is to determine the level of soil $\mathrm{pH}$ and the $\mathrm{pH}$ requirement of the crop. The authors continued that the second step was to apply lime to the soil to either increase or reduce the $\mathrm{pH}$ depending on the level of soil $\mathrm{pH}$ and that of the crop requirement.

Lime is a compound of calcium or magnesium used to correct acidity in the soil. Mamo et al. (2003) postulated that lime is a compound of calcium or calcium and magnesium capable of counteracting the harmful effects of an acid soil in the farm. Brady and Weil (2010) explained that lime is primarily a soil amendment or conditioner and not a fertilizer. The authors mentioned that lime is important to agriculture for it corrects soil acidity, provides vital plant nutrients-calcium and magnesium, reduces the solubility and toxicity of certain elements in the soil such as aluminium, manganese and iron, promotes availability of major plant nutrients and increases bacterial activity, hence induces favourable soil structure and relationships.

The application of lime to the soil is commonly referred 
to as liming. Das (2012) posited liming as the application of basic calcium and magnesium containing materials to agricultural soil with the objective of reducing or increasing soil acidity. Huber et al. (2006) and Reid and Watmough (2014) stated that the application of calciumand magnesium- rich materials to the soil to neutralize soil acidity and increase activity of soil bacteria is called liming. The authors cautioned that over liming or under limining may be harmful to plant life and require treatment. Therefore, to avert the effect of over or under liming of agricultural farms in North-Central Nigeria, it become necessary that the student teachers of agricultural education acquires the required practices in soil $\mathrm{pH}$ management to effectively teach the students in junior secondary schools during their teaching practice.

A practice, in the submission of Miriam (2012), is a process of carrying out an idea, plan or theory. It entails a usual pattern of action or established way of doing something that has been developed through experience and knowledge. With reference to this study, practices refer to step-by-step actions in soil $\mathrm{pH}$ management that was established through experience and knowledge of the experts in the field. It involves all the actions or tasks in determining soil $\mathrm{pH}$, liming to increase soil $\mathrm{pH}$ and liming to reduce soil $\mathrm{pH}$ that are required by practicing teachers of agricultural education to demonstrate soil $\mathrm{pH}$ management to students in junior secondary schools for effective learning. Demonstrating practices in soil $\mathrm{pH}$ management to students in junior secondary school is very important because it enhances the learning and retention of knowledge and skills for crop production after graduation. Besides, Olaitan et al. (1999) asserted that to achieve effective learning in vocational education, the process of performing operations demonstrated by a teacher should be a replica of what is obtained in the field of work.

However, it was observed by one of the researchers that over 7 years of teaching practice supervision while in a College of Education, no practicing teacher has demonstrated soil pH management to students in junior secondary schools even when it was one of the topics taught to students during the term. On a focussed examination of the scheme of work during the supervision, it was discovered that the practicing teachers intentionally avoided teaching the topic to the students. A preliminary study carried out by researchers in May and June 2014 on the practicing teachers from Colleges of Education in North-Central Nigeria revealed that the practicing teachers tactfully avoided the topic during instruction due to lack of competence to demonstrate soil $\mathrm{pH}$ management as recommended in the curriculum. The result of the preliminary study confirmed the suspicion of the researchers that the practicing teachers may lack the required competence to demonstrate soil $\mathrm{pH}$ management to the students. This is in line with a Latin proverb which says 'Nemo dat quod non habet', meaning that none gives out what one does not have. The implication is that, for the practicing teachers to be able to demonstrate determination of soil $\mathrm{pH}$, liming to increase soil $\mathrm{pH}$ and liming to reduce soil $\mathrm{pH}$ to students in junior secondary schools, there is a need to identify the practices involved in the operations. This need gave the present researchers concern since there is dearth of identified practices of soil $\mathrm{pH}$ management in literature that could be used by the lecturers of Agricultural Education in Colleges of Education to prepare their students prior to teaching practice exercise.

Therefore, the purpose of this study was to identify the practices required by practicing teachers of agricultural education for effective teaching of soil $\mathrm{pH}$ management to students in junior secondary schools in North-Central Nigeria. Specifically, the study sought to identify practices in:

1. determining soil $\mathrm{pH}$

2. liming to increase soil $\mathrm{pH}$ and

3. liming to reduce soil $\mathrm{pH}$.

\section{Research questions}

1. What are the practices required by practicing teachers of agricultural education in determining soil $\mathrm{pH}$ for effective teaching of students in junior secondary schools?

2. What are the practices required by practicing teachers of agricultural education in liming to increase soil $\mathrm{pH}$ for effective teaching of students in junior secondary schools?

3. What are the practices required by practicing teachers of agricultural education in liming to reduce soil $\mathrm{pH}$ for effective teaching of students in junior secondary schools?

\section{Research hypotheses}

1. There is no significant difference in the mean ratings of the responses of the lecturers of Agricultural Education in Colleges of Education and Universities in North-Central Nigeria on the practices needed by practicing teachers of Agricultural Education in determining soil $\mathrm{pH}$ for effective teaching of students in junior secondary schools.

2. There is no significant difference in the mean ratings of the responses of the lecturers of Agricultural Education in Colleges of Education and Universities in North-Central Nigeria on the practices needed by practicing teachers of Agricultural Education in liming to increase soil $\mathrm{pH}$ for effective teaching of students in junior secondary schools.

3. There is no significant difference in the mean ratings of the responses of the lecturers of Agricultural Edu- 
cation in Colleges of Education and Universities in North-Central Nigeria on the practices needed by practicing teachers of Agricultural Education in liming to reduce soil $\mathrm{pH}$ for effective teaching of students in junior secondary schools.

\section{Significance of the study}

The beneficiaries of this study are the students and lecturers of agricultural education in Colleges of Education, students in junior secondary schools and their parents. The study identified the practices in determination of soil $\mathrm{pH}$, liming to increase soil $\mathrm{pH}$ and liming to reduce soil $\mathrm{pH}$. The information provided from the study will be used by the lecturers of agricultural education to equip their students with the knowledge and skills in soil $\mathrm{pH}$ management for effective teacher preparation in Colleges of Education. The students of agricultural education in Colleges of Education will utilize the information provided by the study to demonstrate soil $\mathrm{pH}$ management to the students in junior secondary schools during teaching practice.

Students in junior secondary schools will benefit from the study for they would learn faster and retain the competence in practices in soil $\mathrm{pH}$ management more than if it were not demonstrated by the practicing teachers from Colleges of Education. The parents will benefit from the findings of the study if their children demonstrate the acquired practices in determining soil $\mathrm{pH}$, liming to increase soil $\mathrm{pH}$ and liming to reduce soil $\mathrm{pH}$ in their parents' farm to maximize crop yield.

\section{Scope of the study}

The study was restricted to identification of practices require by practicing teachers of agricultural education for effective teaching of soil $\mathrm{pH}$ management to students in junior secondary schools in North-Central Nigeria. The study covered practices in determining soil $\mathrm{pH}$, liming to increase soil $\mathrm{pH}$ and liming to reduce soil $\mathrm{pH}$ for effective teaching of soil $\mathrm{pH}$ management to students in junior secondary schools. It was also restricted to the use of questionnaire for data collection from the lecturers of agricultural education in Colleges of Education and Universities in North-Central Nigeria only.

\section{METHODOLOGY}

Three research questions were developed and answered by the study while three null hypotheses were formulated and tested. Questionnaire survey research design was used for this study. Questionnaire was used to collect data from the respondents (lecturers of Agricultural Education) through mail and face-to-face basis and the findings were generalized on the population of the lecturers of Agricultural Education in the study area. The study was carried out in North-Central zone of Nigeria made up of Benue, Nasarawa, Kwara, Kogi and Niger states and the Federal Capital Territory. The population of the study was 55, made up of 32 lecturers of agricultural education in Colleges of Education and 23 lecturers of agricultural education in universities (Heads of Departments in Colleges of Education and universities offering Agricultural Education programme). The entire population was involved in the study, hence there was no sampling.

An instrument titled: Soil pH Practices Questionnaire (SPPQ) was developed by the researchers from personal experiences and literature reviewed and was used for data collection. The SPPQ had a 4-point response scale of highly required, averagely required, slightly required and not required with a corresponding value of $4,3,2$ and 1 respectively. The instrument was face validated by 3 experts; one from the Department of Soil Science, Federal University of Agriculture, Makurdi, one from the Department of Vocational Teacher Education, University of Nigeria, Nsukka, and one from the Department of Agricultural Education, Federal College of Education, Eha-Amufu, Enugu State. Their corrections and suggestions were used to improve the initial draft of the questionnaire for production of the final edition. Thirty (30) copies of the questionnaire were administered to lecturers of Agricultural Education in Colleges of Education and universities in South-East to determine the reliability of the SPPQ items. Cronbach Alpha reliability method was used to determine the internal consistency of the SPPQ items. A Cronbach Alpha coefficient of 0.89 was obtained, meaning that the instrument was highly reliable. Five research assistants who were familiar with the area of the study were employed and given orientation on how to administer the questionnaire to the respondents. Fifty-five copies of the questionnaire were administered to the respondents through mail and faceto-face contact but only fifty-three copies were returned and analyzed.

The data collected was analyzed using weighted mean and standard deviation which were used to answer the research questions and t-test for testing the null hypotheses at 0.05 level of probability and at 51 degree of freedom. A mean of 2.50 was used for decisionmaking. Any item with a mean value of 2.50 or above was regarded as a practice that is needed while any item with a mean less than 2.50 was regarded as not needed. In testing the hypothesis, a null hypothesis of no significant difference was accepted where $p$-value was greater than 0.05 level of probability but rejected where $p$-value was less than 0.05 level of probability.

\section{RESULTS}

The results for the study were obtained from the research questions answered and hypothesis tested through data collected and analyzed in Table 1 to 3. 
Table 1. Mean Ratings and t-test Analysis of the responses of lecturers of Agricultural Education in Colleges of Education and universities on determination of soil $\mathrm{pH}(\mathrm{N}=53)$.

\begin{tabular}{|c|c|c|c|c|c|}
\hline $\mathbf{S} / \mathbf{N}$ & Practices on determining soil $\mathrm{pH}$ & Mean & SD & P-value & Remark \\
\hline 1 & Collect soil sample from different locations in the farm & 3.03 & 0.40 & 0.48 & RQ NS \\
\hline 2 & Weigh out $5 \mathrm{~g}$ of soil into a labelled $50 \mathrm{~m}$ plastic (polypropylene) tube & 2.84 & 0.45 & 0.81 & RQ NS \\
\hline 3 & Add $25 \mathrm{ml}$ of distilled water to the labelled tube & 3.16 & 0.84 & 0.55 & RQ NS \\
\hline 4 & Add $25 \mathrm{ml}$ of $1 \mathrm{mkCl}$ to the tube & 3.25 & 0.67 & 0.34 & RQ NS \\
\hline 5 & Add $25 \mathrm{~cm}$ of $0.001 \mathrm{~m} \mathrm{CaCl} 2$ to the tube & 3.00 & 0.50 & 0.86 & RQ NS \\
\hline 6 & Shake the tube vigorously for 1 hour at room temperature $\left(25^{\circ} \mathrm{C}\right)$ & 3.44 & 0.63 & 0.80 & RQ NS \\
\hline 7 & Keep the solution to settle for about 3 minutes & 3.86 & 0.38 & 0.12 & RQ NS \\
\hline 8 & Perform 2 replicates of the soil solution for each soil sample & 2.98 & 0.79 & 0.24 & RQ NS \\
\hline 9 & $\begin{array}{l}\text { Measure the } \mathrm{p}^{\mathrm{H}} \text { after a two point }(\mathrm{pH} 4 \text { and } \mathrm{pH} 7) \text { using calibration of the } \mathrm{pH} \\
\text { meter }\end{array}$ & 3.24 & 0.42 & 1.37 & RQ NS \\
\hline 10 & Observe the level of the soil $\mathrm{pH}$ on the $\mathrm{pH}$ meter & 3.60 & 0.36 & 0.71 & RQ NS \\
\hline 11 & $\begin{array}{l}\text { Record the observations such as acidic (below 7), neutral ( } 7 \text { ) and alkaline } \\
\text { (above). }\end{array}$ & 2.71 & 0.59 & 0.39 & RQ NS \\
\hline 12 & $\begin{array}{l}\text { Calculate the quantity of lime required to reduce or increase the soil } \mathrm{pH} \\
\text { based on the result }\end{array}$ & 3.80 & 1.08 & 0.72 & RQ NS \\
\hline
\end{tabular}

SD, standard deviation, $\mathbf{R Q}$, required, NS, not significant.

The data in Table 1 showed that all the 12 items had their mean values ranging from 2.71 to 3.86 and were above the cut of point of 2.50. This indicated that the respondents agreed that all the items were practices required by practicing teachers of Agriculture in determination of soil $\mathrm{pH}$ for effective teaching of soil $\mathrm{pH}$ management to students in junior secondary schools. The Table 1 showed that the standard deviation of the items ranged from 0.36 to 1.08 which means that the respondents were not too far from the mean and opinion of one another in the responses.

The data on hypothesis tested in Table 1 revealed that all the 12 items had their p-values ranging from 0.12 to 1.37 which were greater than the alpha-value of 0.05 . This implied that there was no significant difference in the mean ratings of the responses of lecturers of agricultural education in Colleges of Education and universities on the practices required by practicing teachers of Agriculture in determination of soil $\mathrm{pH}$ for effective teaching of soil $\mathrm{pH}$ management to students in junior secondary schools. Therefore, the hypothesis of no significant difference was upheld for each of the items in the determination of soil $\mathrm{pH}$ for effective teaching of students in junior secondary schools in North-Central Nigeria.

The data in Table 2 showed that all the 12 items had their mean values ranging from 2.81 to 3.96 and were above the cut of point of 2.50. This indicated that the respondents agreed that all the items were practices required by practicing teachers of Agriculture in liming to increase soil $\mathrm{pH}$ for effective teaching of soil $\mathrm{pH}$ management to students in junior secondary schools. The Table 2 showed that the standard deviation of the items ranged from 0.26 to 0.74 which means that the respondents were not too far from the mean and opinion of one another in the responses.

The data on hypothesis tested in Table 2 revealed that all the 12 items had their $p$-values ranged from 0.42 to 1.29 which were greater than the alpha-value of 0.05 . This implied that there was no significant difference in the mean ratings of the responses of lecturers of agricultural education in Colleges of Education and universities on the practices required by practicing teachers of Agriculture in liming to increase soil $\mathrm{pH}$ for effective teaching of soil $\mathrm{pH}$ management to students in junior secondary schools. Therefore, the hypothesis of no significant difference was upheld for each of the items in liming to increase soil $\mathrm{pH}$ for effective teaching of soil $\mathrm{pH}$ management to students in junior secondary schools in North-Central Nigeria.

The data in Table 3 showed that all the 12 items had their mean values ranging from 2.92 to 3.80 and were above the cut of point of 2.50 . This indicated that the respondents agreed that all the items were practices required by practicing teachers of Agriculture in liming to reduce soil $\mathrm{pH}$ for effective teaching of soil $\mathrm{pH}$ management to students in junior secondary schools. The Table 3 showed that the standard deviation of the items ranging from 0.76 to 1.48 which means that the respondents were not too far from the mean and opinion of one another in the responses.

The data on hypothesis tested in Table 3 revealed that all the 12 items had their $p$-values ranging from 0.10 to 1.04 which were greater than the alpha-value of 0.05 . This implied that there was no significant difference in the mean ratings of the responses of lecturers of agricultural education in Colleges of Education and universities on the practices required by practicing teachers of Agricul- 
Table 2.Mean Ratings and t-test Analysis of the responses of lecturers of Agricultural Education in Colleges of Education and universities on liming to increase soil pH (N=53).

\begin{tabular}{|c|c|c|c|c|c|}
\hline $\mathrm{S} / \mathrm{N}$ & Practices onlimining to increase soil pH & Mean & SD & $P$-value & Remark \\
\hline 1 & $\begin{array}{l}\text { Source lime such as wood ash locally or pelleted/powdered calcitic or } \\
\text { dolomotized lime from the market }\end{array}$ & 3.53 & 0.30 & 1.29 & RQ NS \\
\hline 2 & Decide on when to apply lime, preferably after pre-planting operation & 2.94 & 0.35 & 0.99 & $R Q N S$ \\
\hline 3 & Secure spreader or materials for applying lime to the soil such as plate or cup & 3.26 & 0.74 & 0.85 & RQ NS \\
\hline 4 & Wear protective clothe such as google, hand glove and apron & & & & \\
\hline 5 & $\begin{array}{l}\text { Study the instruction manual on the packet of lime and the spreader for } \\
\text { accurate application. }\end{array}$ & 3.35 & 0.57 & 0.64 & RQ NS \\
\hline 6 & $\begin{array}{l}\text { Measure out the quantity of lime required for the land based test } \\
\text { recommendation }\end{array}$ & 3.10 & 0.41 & 1.06 & RQ NS \\
\hline 7 & Spread the lime at $45 \mathrm{~kg} / 1 \mathrm{~km}^{2}$ or $92 \mathrm{~m}^{2}$ of land at a time & 3.54 & 0.53 & 1.00 & $R Q N S$ \\
\hline 8 & $\begin{array}{l}\text { Walk horizontally forth and back across the farm land until the entire area is } \\
\text { covered with the lime }\end{array}$ & 3.96 & 0.28 & 0.42 & RQ NS \\
\hline 9 & Repeat the process walking vertically to ensure that no spot is left uncovered & 3.08 & 0.69 & 0.54 & RQ NS \\
\hline 10 & $\begin{array}{l}\text { Water the land lightly if the soil is dry to help the lime dissolve into the soil } \\
\text { without being washed away }\end{array}$ & 3.44 & 0.32 & 1.07 & RQ NS \\
\hline 11 & $\begin{array}{l}\text { Repeat the process once a month depending on the level of soil } \mathrm{pH} \text { until the } \\
\text { desired } \mathrm{p}^{\mathrm{H}} \text { is reached }\end{array}$ & 3.70 & 0.26 & 1.10 & RQ NS \\
\hline 12 & Test the soil pH after 3-5years before another round of lime application & 2.81 & 0.49 & 0.69 & $R Q N S$ \\
\hline
\end{tabular}

SD, standard deviation, $\mathbf{R Q}$, required, NS, not significant.

Table 3. Mean Ratings and t-test Analysis of the responses of lecturers of Agricultural Education in Colleges of Education and universities in practices on liming to reduce soil $\mathrm{pH}(\mathrm{N}=53)$.

\begin{tabular}{|c|c|c|c|c|c|}
\hline $\mathbf{S} / \mathbf{N}$ & Practices on liming to reduce soil pH & Mean & SD & P-value & Remark \\
\hline 1 & Purchase Sulphuric lime from the market & 3.43 & 0.80 & 0.15 & RQ NS \\
\hline 2 & $\begin{array}{l}\text { Choose time/ decide on when to apply lime, preferably after pre-planting } \\
\text { operation }\end{array}$ & 3.04 & 0.85 & 0.43 & RQ NS \\
\hline 3 & Obtain a plastic plate or cup for applying lime to the soil & 3.36 & 0.94 & 1.04 & RQ NS \\
\hline 4 & Wear protective clothe such as hand glove and apron & 3.45 & 1.07 & 0.71 & RQ NS \\
\hline 5 & $\begin{array}{l}\text { Study the instruction manual on the packet of Sulphuric lime for accurate } \\
\text { application. }\end{array}$ & 3.09 & 0.90 & 0.10 & RQ NS \\
\hline 6 & $\begin{array}{l}\text { Measure out the quantity of lime required for the land based test } \\
\text { recommendation }\end{array}$ & 3.64 & 1.03 & 1.02 & RQ NS \\
\hline 7 & Spread the lime at $45 \mathrm{~kg} / 1 \mathrm{~km}^{2}$ or $92 \mathrm{~m}^{2}$ of land at a time & 3.06 & 0.78 & 0.81 & RQ NS \\
\hline 8 & $\begin{array}{l}\text { Walk horizontally forth and back across the farm land until the entire area is } \\
\text { covered with the Sulphuric lime }\end{array}$ & 3.08 & 1.09 & 0.61 & RQ NS \\
\hline 9 & Repeat the process of walking vertically to ensure that no spot is left uncovered & 3.44 & 0.82 & 0.76 & RQ NS \\
\hline 10 & $\begin{array}{l}\text { Water the land carefully lightly if the soil is dry to help the lime dissolve into the } \\
\text { soil without being washed away }\end{array}$ & 3.80 & 0.76 & 0.67 & RQ NS \\
\hline 11 & $\begin{array}{l}\text { Repeat the process once a month depending on the level of soil } \mathrm{pH} \text { until the } \\
\text { desired } \mathrm{pH} \text { is reached }\end{array}$ & 2.92 & 0.99 & 1.00 & RQ NS \\
\hline 12 & Test the soil pH after 3-5years before another round of lime application & 3.31 & 1.48 & 0.44 & $R Q N S$ \\
\hline
\end{tabular}

SD, standard deviation, $\mathbf{R Q}$, required, NS, not significant.

ture to reduce soil $\mathrm{pH}$ for effective teaching of soil $\mathrm{pH}$ management to students in junior secondary schools. Therefore, the hypothesis of no significant difference was upheld for each of the items in liming to reduce soil $\mathrm{pH}$ for effective teaching of soil $\mathrm{pH}$ management to students in junior secondary schools in North-Central Nigeria.

\section{DISCUSSION}

The results revealed that the practicing teachers of agricultural education from Colleges of Education required 12 practices in determination of soil $\mathrm{pH}, 12$ practices in liming to increase soil $\mathrm{pH}$ and 12 practices in 
liming to reduce soil $\mathrm{pH}$ for effective teaching of soil $\mathrm{pH}$ management to students in junior secondary schools in North-Central Nigeria. The study also revealed that the hypothesis of no significant difference was upheld for all the 36 practices in soil $\mathrm{pH}$ for effective teaching of soil $\mathrm{pH}$ management to students in junior secondary schools in North-Central Nigeria. The implication is that the professional experience and level of institution did not significantly influence the opinion of the respondents on all the practices in soil $\mathrm{pH}$. This added credence to the result of this study.

The findings are in agreement with the findings of Zemelman et al. (2005) in a study on best practice: Today's Standards for Teaching and Learning in America's Schools that there are 11 best practices in teaching mathematics, 5 best practices in problem solving in mathematics, 7 best practices in creating representations in mathematics among others. Grover (2013) who found out that the best practices in education in US include a clear and common focus; high standard and expectations; strong leadership; supportive, personalized and relevant learning; parents/community involvement; monitoring, accountability and assessment; curriculum and instruction; professional development and time and structure. The study is also in harmony with the findings of Asogwa (2014), who found that 11 educational practices in broadcasting of fertilizer, 11 educational practices in placement of fertilizer, 10 educational practices in foliar method of fertilizer application and 11 educational practices in fertilizer management were needed by practicing teachers of agriculture for demonstrating fertilizer application in a school farm to students in junior secondary schools. The findings of the authors cited above helped to add validity to the findings of this study in North-Central Nigeria.

\section{Conclusion}

It was discovered that the practicing teachers in junior secondary schools intentionally avoided teaching chemical properties of soil especially soil $\mathrm{pH}$ to the students due to the demonstration method of teaching that is recommended in the curriculum. This is because the practicing teachers lack knowledge and skills in the practices required in the determination of soil $\mathrm{pH}$, liming to increase soil $\mathrm{pH}$ and liming to reduce soil $\mathrm{pH}$ for effective teaching of soil $\mathrm{pH}$ management to the students. Besides, there are no identified practices in soil $\mathrm{pH}$ in the literature that could be used by the lecturers of Agricultural Education in Colleges of Education in preparing their students prior to teaching practice exercise in junior secondary schools. To this effect, the study was carried out to identify the practices required by practicing teachers of agricultural education for effective teaching of soil $\mathrm{pH}$ management to students in junior secondary schools in North-Central Nigeria. It was found out that the practicing teachers of agricultural education from Colleges of Education required 12 practices in determination of soil $\mathrm{pH}, 12$ practices in liming to increase soil $\mathrm{pH}$ and 12 practices in liming to reduce soil $\mathrm{pH}$ for effective teaching of students in junior secondary schools in North-Central Nigeria.

\section{Recommendations}

Based on the findings of the study, it was recommended that:

1. lecturers of Agricultural Education in Colleges of Education should utilize the identified practices in soil $\mathrm{pH}$ to train their students in Colleges of Education.

2. practicing teacher should rehearse the practices identified in this study before teaching soil $\mathrm{pH}$ to students in junior secondary schools in Benue State.

3. teachers of Agriculture in junior secondary schools should utilize the practices in teaching soil $\mathrm{pH}$ to their students.

\section{CONFLICT OF INTEREST}

The authors declare that they have no conflict of interest.

\section{REFERENCE}

Anderson, N. P, Hart, J. M, Sullivan, D. M, Christensen, N. W, Horneck, D. A., \& Pirelli,G.J. (2013). Applying Lime to Raise Soil $\mathrm{pH}$ for Crop Production (Western Oregon). Fertilizer and Lime Materials Fertilizer Guide: OSU Extension publication FG 52, Pp. 34-35.

Asogwa, V. C. (2014). Educational practices needed by practicing teachers of agriculture for demonstrating fertilizer application in a school farm to students in junior secondary schools in Enugu State, Nigeria. Review of Education, Institute of Education Journal, University of Nigeria, Nsukka, 25(1), 118-136.

Brady, N. C., \& Weil, R. R. (2010). Elements of the nature and properties of soils. New York, Person Education International, Pp. 341 - 244.

Das, D. K. (2012). Introduction to soil science. West Bengal, India: Kalyani Publishers, Pp. $234-256$.

Farlex, M. (2009). The free Dictionary. The American Heritage ${ }^{\circledR}$ Dictionary of the English Language, Fourth Edition: Houghton Mifflin Company, p. 1379.

Gale, J, Koenig, R., \& Barnhill, J. (2001). Managing Soil PH In Utah: An electronic publication of Utah State University Extension. Retrieved from http://nijesr.iefr.edu.pk/ journalFolder/7/24cf4.pdf on 14th July, 2014.

Gliessman, S. R. (1998). Agroecology: Researching the Ecological Processes in Sustainable Agriculture. In: Chou, C.H. and K.T. Shan (eds). Frontiers in Biology: The Challenge of Biodiversity, Biotechnology, and Sustainable Agriculture. Academia Sinica, Taipei, Taiwan, Pp 70-72.

Grover, J. W. (2013). Best Practices in Education. US: Educational Research and Improvement, U.S. Department of Education, p. 361.

Huber, C., Baier, R., Göttlein, A., \& Weis, W. (2006). Changes 
in soil, seepage water and needle chemistry between 1984 and 2004 after liming an N-saturated Norway spruce stand at the Höglwald, Germany. Forest Ecology and Management, 233(1), 11-20.

Reid, C., \& Watmough, S. A. (2014). Evaluating the effects of liming and wood-ash treatment on forest ecosystems through systematic meta-analysis. Canadian Journal of Forest Research, 44(8), 867-885.

Kasanda, C. D. (1995). Teaching practice at the University of Namibia: Views from student teachers. Zimbabwe Journal of Educational Research, 7, 57-68.

Mamo, M., Wortmann, C. S., \& Shapiro, C. A. (2003). Lime use for soil acidity management. Cooperative Extension, Institute of Agriculture and Natural Resources, University of NebraskaLincoln.

Martin, R. A. (1991). The Essence of Agricultural Education. Agricultural Education, 63(8), 21-22.

Menter, I. (1989). Teaching Stasis: Racism, sexism and school experience in initial teacher education. British Journal of Sociology of Education, 10, 459-473.

Miriam, M. (2012). Meaning of Practice. Miriam Dictionary. Retrieved webster.com/dictionary/dictionary on $25^{\text {th }}$ March, 2012.

National Commission for Colleges of Education (NCCE) (2009). Minimum Standard for Nigeria Certificate in Education (NCE) Teachers, Vocational and Technical Education, (4 ${ }^{\text {th }}$ Edition). Abuja NCCE, Pp 23.

National Policy on Education (NPE) (2004). Federal Government of Nigeria.Yaba: NERDC press.

Ngidi, D. P., \& Sibaya, P. T. (2003). Student teacher anxieties related to practice teaching. South African Journal of Education, 23, 18-22.
Olaitan, S. O. Nwachukwu, C. E, Onyemachi, G. A., Igbo C. A., \& Ekong, E. O. (1999). Curriculum Development and Management in Vocational Technical Education. Onitsha: Cape Publishers International Limited, Pp. 53-61.

Osborne, P., Ball, D., Edward, L., \& Anna, J. (2008). Handbook on Agricultural Education in Public Schools Sixth Edition. NY: Delmar Learning. p. 129.

Salawu, O., \& Adeoye, A. (2002). Unit 1 the co1pt of student teaching practice. Retrieved from http://crsps.net/wpcontent/downloads/Soil\%20Management/Inventoried\%209.27 16-2008-1-28.pdf 3rd April, 2012.

Williams, D. L. (1991). Focusing Agricultural Education Research, Strategies for the Discipline.Journal of Agricultural Education, 32(1), 7-12.

Yost, R. S., \& Uchida, R. (2000). Plant Nutrient Management in Hawaii's Soils, Approaches for Tropical and Subtropical Agriculture, Pp. 133-143.

Zemelman, S, Daniels, H., \& Hyde, A. (2005). Best Practice: Today's Standards for Teaching and Learning in America's Schools. USA: Heinemann, a division of Reed Elsevier, Inc., Portsmouth, NH. Retrived from https://www.amazon.com/Practice-StandardsTeaching-Learning-Americas/dp/0325007446 on 15th July, 2014. 